\title{
A Study on English Learning Dynamics in Pre- primary Schools
}

\author{
Margarita Pino Juste \\ University of Vigo \\ BEATRIZ RODRÍGUEZ LÓPEZ \\ Universidad Nacional de Educación a Distancia (UNED)
}

Received: 2 June 2009 / Accepted: 20 November 2009

ISSN: $1697-7467$

\begin{abstract}
In this article, the dynamics used by EFL teachers in Galicia (Spain) in pre-primary schools are examined by means of a case study. Among the most important conclusions of the study we highlight the fact that the methodology used is active, participative and globalised; the learner becomes the main protagonist of his/her own learning; an individualized methodology is used in order to adapt the teaching to the personal characteristics of each learner, and all this facilitates the learning process. In this context, games hold a central role as a motivational teaching strategy.

Key words: Foreign language teaching, methodology, didactics, English, young learners.
\end{abstract}

\section{Estudio sobre las dinámicas de aprendizaje en Inglés en Educación Infantil}

RESUMEN: En este artículo se describen las dinámicas utilizadas por profesores de inglés como lengua extranjera en Galicia (España) a través de un estudio de caso. Entre las conclusiones más importantes destacamos que la metodología utilizada es ante todo activa, participativa y globalizada. Es decir, el alumno resulta ser el principal protagonista de su propio aprendizaje; se emplea una metodología individualizada, para adaptar la enseñanza a las características personales de cada alumno con el fin de facilitarles el aprendizaje. En este contexto el juego tiene un papel preponderante como estrategia didáctica de motivación.

Palabras clave: Enseñanza de la segunda lengua, Metodología, Didáctica, Inglés, Educación Infantil

\section{TheORETICAL FRAMEWORK}

After an initial search for literature on Foreign Language teaching methodologies in Preprimary School, we have found that the only specific references to the topic cannot in truth be defined as methodologies, but rather as reflections, proposals, models, exemplifications or suggestions made by a number of authors, normally as a result of their analysis of their own teaching experience in Pre-primary School or about learning strategies (Chamot et al.,1999; Cohen and Macaro, 2007; O’Malley and Chamot,1990; Oxford, 1990; Chamot, 2004; Cohen, 1998). 
Authors such as Stern \& Weinrib (1977), Dunn (1983, 1985), Ellis (1994), Halliwell (1993) and Ashworth \& Wakefield (1994), Rodríguez Sánchez \& McArthur (2001), Gálvez Díaz, (2001) and, most particularly in the Spanish context Mur (1998), among many others, have reflected on the introduction of foreign language teaching at an early age, analysing its particular characteristics and indicating the need for a specific methodology which caters for the needs of this stage of education.

In their studies, these authors offer a number of suggestions for the teaching-learning of foreign languages in Pre-primary School. We also find recommendations and suggestions for language teaching which examine in detail the evolutionary characteristics of young learners, the most appropriate methodological resources for approaching the foreign language, the adaptation of narrative resources to this age-group and the planning of projects on early language acquisition.

Due to its relationship to this investigation, it is important to make reference to the work done by López Rodríguez (2001) regarding the difficulties rural schools find in their attempt to teach English in a suitable manner. The study analyses the fact that boys and girls of different levels share the same classroom and puts forward a proposal for the use of a modular programme for teaching the foreign language. This author suggests the use of a single book, called «module», which can be used for the entire group of activities that are specific to each level. The author's investigation tries to show that in rural schools, education can and must be carried out in a different manner.

The aim of our study is to discover which dynamics are most commonly used in the teaching of English at Pre-primary School in rural areas and to favour a description of the possible implications in order to implement similar experiences in different contexts and to design new methodological strategies that facilitate the command of a foreign language.

\section{STUdy}

\subsection{Participants}

Learners, parents, teaching staff and tutors specialised in Pre-primary education, as well as teachers of English, took part in this study.

The study was carried out in the three Rural School Groups $(R S G)$ situated in the Baixo Miño region of Galicia (North-West Spain) during the academic year of 2007-08. This region is basically rural. RSG's are groups of schools, each of which has, in most cases, a single classroom where children aged 3-6 study together. They are in a rural environment where the population is scattered. In this way, children attend the school that is nearest to them, thus avoiding long journeys, and the teaching is adapted to the characteristics of the environment, taking into account the ages of the children.

A total of three hundred and ninety-four children are registered in Pre-primary School. The study is based on a population of three hundred and ninety families. A total of two hundred and forty questionnaires were collected. The average age of the participating parents is 30.5 for mothers and 33.96 for fathers. The teachers must be divided into two groups. The first group comprises thirty-one tutors (Pre-primary Education specialists). In the second group there are three teachers specialised in English, one for each RSG. 


\subsection{Methodology}

This investigation has followed a descriptive approach we have used a variety of data gathering instruments: video recordings of classroom activities, life stories of the specialist English teachers, interviews with the head teachers, questionnaires answered by tutors and parents, and the analysis of the contents of the school syllabus and didactic programmes.

The observation methodology of this study was carried out in a number of stages, following Del Rincón et al (1995: 229), starting with the setting of objectives. It was essential to set clear objectives derived from the attitudes and conducts to be observed due to their interest regarding the topic of the study. These conducts and attitudes were selected after a first stage of informal observation.

The strategy to be used was decided in a second stage, it being of an inductive type. Another criterion taken into account was the need for systematic, non-participative observation. We analysed non-verbal, spatial, oral/vocal and verbal conducts. During the analysis of the methodological techniques used by teachers it was necessary to observe all the aspects of their conduct, that is to say, non-verbal conduct: use of mime, facial and body expression, gestures, etc.; spatial conduct: class dynamics, movement games, etc.; oral/vocal conduct: use of onomatopoeic words, sound imitation, etc.; verbal conduct: use of L1 and L2, etc. Lastly, specific difficulties and the observer's training were also taken into account.

The next stage was the gathering and classification of data. The data was subsequently analysed by means of the transcription of all the information and analysis of the various categories found.

The final stage was the interpretation of the results, starting with a methodological selfcriticism of the various stages of the process and the review of the use of observational methodology. This was followed by several readings of these transcriptions in order to identify the categories, topics, attitudes and behaviours which might be of interest for the purposes of the study.

In this study, as it was directed at Pre-primary education, the video recording was particularly useful for discovery and validation because it provided documentation of non-verbal communication and behaviour, such as expressions of emotions and facial gestures, which are especially common at this stage, in their original form. Also, these recordings may be used in future instances with other visualization, analysis and comprehension methods.

A fixed camera was used, situated at a strategic point of the classroom from where everything that went on could be easily observed. This option was chosen because it interferes least with the normal development of classroom activity. If the researchers themselves or another person had operated the camera, the pupils' attention would have been distracted by this stranger to their environment, and it might also have distracted the teacher, who might have felt uncomfortable when carrying out certain activities.

Subsequently, all the recordings were reviewed, using the category system selected previously; images were not transcribed, but were studied directly. This decision was taken because verbal language is a very powerful and effective means of expression for our investigation purposes. Thus, Navarro and Díaz (1994) assert that these expressions can be oral or written, as in the case of this study. All things considered, the work is always done on the basis of texts, because verbal language must be transcribed into written texts. 
Oral materials taken from the video recordings, as well as life histories and other materials gathered by the researchers from the observation stage and from institutional documents, were used in this investigation. Regarding the analysis of document contents, the intention is to establish the type of behaviour within the didactic sphere and how the meaning of the action is expressed. The life histories were used to understand how teachers face everyday challenges (Marshall \& Rossman, 1989).

In this particular study, we have used the life histories of the three English teachers. The researchers conducted recorded conversations during which, following some guidelines, the teachers talked about their personal experiences as teaching professionals and their personal experiences as teachers of English in Pre-primary School.

The aim of the parents' questionnaire was to find out their level of knowledge of other languages, the language learning resources existing in their homes and their attitude towards this type of learning. Care has been taken to maintain the subjects' anonymity; also, some place names and people's names have been altered to prevent the identification of certain situations.

The process of categorizing the information was carried out by isolating units or segments of contents relevant to the investigation. Analysis is carried out by means of fragmenting the text into specific elements. In this investigation, categorisation was carried out according to topical criteria because this allowed a greater level of systematisation of the categories, and therefore of the data. Subsequently, this data was coded in order to facilitate the description, understanding and exploration of the topic under study. The conceptual structure presented in this article is derived from a naturalistic categorisation which emerges from the data itself (Goetz y LeCompte, 1988).

The categories selected were examined through qualitative processes of content analysis, complemented by statistics of frequency and percentage (Rodríguez, Gil \& Garcia, 1999).

The reliability of category encoding was discussed and agreed upon with a group of researchers who collaborate with the project (Goetz \& LeCompte, 1988).

Table 1: Summary of instruments used in the study Source: article authors.

\begin{tabular}{|l|l|l|}
\hline INSTRUMENT & POPULATION & OBJECTIVE \\
\hline Questionnaire & Parents & $\begin{array}{l}\text { Linguistic resources in the } \\
\text { family }\end{array}$ \\
\hline Life Histories & Specialist teachers & $\begin{array}{l}\text { Understanding the solutions } \\
\text { proposed }\end{array}$ \\
\hline Interviews & $\begin{array}{l}\text { Tutors } \\
\text { Head teachers }\end{array}$ & $\begin{array}{l}\text { Reasons for the strategies } \\
\text { proposed } \\
\text { Pedagogical evaluation }\end{array}$ \\
\hline Observations & Classroom & Learning Dynamics \\
\hline Video recordings & Classroom & Learning Dynamics \\
\hline Content Analysis & $\begin{array}{l}\text { Classroom lesson plans } \\
\text { School syllabus }\end{array}$ & $\begin{array}{l}\text { Theoretical approach to teaching } \\
\text { activities }\end{array}$ \\
\hline
\end{tabular}




\section{Analysis and results}

The conclusions arrived at in each category are shown below. We would like to note that this analysis has been designed bearing in mind the possibility of extrapolating these results to other educational contexts so this experience can be useful to other teachers.

\subsection{The activity principle}

To begin with, we must bear in mind that when dealing with the methodology for Preprimary Education, the DCB does not prescribe any specific methodology; that is to say, there is no single method, or methods that are considered better or worse; for this reason the methodology to be used must simply be that which is considered most adequate to the needs and characteristics of the group. However, in the classroom lesson plans of the schools studied, there are specific references to the methodology to be used.

Thus, in these schools the methodology used is basically active, that is, the learner is the protagonist of his/her own learning. For this reason, one of the main objectives is to facilitate learning through the active participation of learners, designing activities which they find attractive and which imply active participation. One of the English teachers points this out in the interview:

The fact that these pupils are so active and never stop moving is a determining factor of the type of activities one can do with them, not all activities are suitable; if you don't plan activities which are interesting and dynamic they get bored very easily and they don't participate, they just switch off or bother you. They are much more demanding than older pupils (STLSRSGR).

In this way, these activities are the basis of the building of their knowledge, and children are considered as subjects and protagonists of the educational process, and not as mere «objects» to be educated.

Taking into account that the main characteristic of Pre-primary School children is their great curiosity, the activities and tasks planned must imply action, manipulation and exploration of their natural environment. As the teachers say: «My methodology is active, in so far as it is basically kinaesthetic: all activities imply learning by doing» (STLSRSGTO).

The basic principle for these teachers is to let the children manipulate, explore, experiment and discover the things they have to learn, so the teachers try, as far as possible, to accompany each activity with real-life elements, e.g. a plant, etc. which the children can smell, touch, see... in other words, explore with their senses. An example can be found in this comment made by a teacher:

... I take many real objects to the classroom: fruit, vegetables, pasta, because I use them in the activities, as children can touch, smell and then eat them; we do the same with them in English as they do with the other teacher and we work with «like» and «don't like», colours, etc. ...it's very sense-oriented and they love it (STLSRSGR).

The objective of these activities is the sensory perception and manipulation of objects which will help the children to perceive the qualities and properties of said objects, such as the colour of fruit, leaves, etc., to establish similarities and differences. 
All in all, observation and experimentation are the most natural companions of children in the process of building their own knowledge, and for this reason they must be encouraged by means of nature trips or by bringing the objects into the classroom, always bearing in mind that the context must be familiar to them: «we deal with topics which are familiar to the children, we look at means of transport, family, food, etc, all of them already known, they talk about these topics in their mother language, they are real things which are a part of their everyday life» (STLSRSGTO).

\subsection{Globalisation as an organizational technique}

In these schools the methodology used is basically active, that is, the learner is the main protagonist of his/her own learning. For this reason, the goal of all these activities is the sensory perception and manipulation of objects which may help children appreciate the qualities and properties of these objects, such as the colour of fruit, leaves, etc., and to establish similarities and differences.

The methodology used is globalised, so the activities which have been designed envisage the simultaneous or successive use of different types of contents and different areas of knowledge. That is to say, each activity does not work with a specific area of content, but it may incorporate other attitudes or habits, crosscurricular topics, intersubject links, etc. In the same way, whenever possible, new contents are linked to already existing knowledge.

The methodology used can also be called creative, as it is important that children are able to express what they feel, see, etc. through some kind of personal creation, be it oral, artistic, etc.: "It is much more rewarding, it allows you to use your imagination, and you can be more resourceful in designing activities that they enjoy, you can be more creative than with older pupils» (STLSRSGR).

\subsection{Individualization as the basis of the learning process}

Another important aspect is the use of an individualised methodology in order to adapt teaching to the personal characteristics of each pupil and thus facilitate learning. Thus, Cole (1994: 191) explains that it is necessary «... to accept individual differences, trying to adapt education to these characteristics, so, in catering to individual differences we are giving our children equal opportunities». We must be aware of the fact that in each classroom there are about twenty-five individuals with different needs and characteristics. For example, when volunteers are needed to demonstrate something, we can ask the cooperation of those children who need practical examples, more attention, etc.

We have observed that, in spite of some children's constant demand for participation, the teachers usually select those who are considered most in need of special attention. As one of the teachers says:

We have to be very careful at this stage, at all stages really, but I think especially at this one, about giving individual attention to each child or else the same ones always answer, come out to the front of the class, or do the activities, and there is a group of pupils, perhaps the youngest or the shyest or most easily embarrassed who never open their mouths. I try to pay special attention to them and control 
the others to let them participate, without forcing them to do so, because sometimes it can be worse; you have to let them go at their own pace but ensure that they have opportunities. In particular, when you have a pupil with a special problem, for example a Down syndrome child I have, who also participates when he feels like it, but learns quite a lot (STLSRSGT).

Besides the above mentioned aspects, an adequate methodology must take into account the importance of establishing a warm relationship with the pupils as a necessary condition for any kind of learning to take place. The children will only feel ready to participate in the activities if they are relaxed and at ease. Another teacher gives an example of the importance of trust in the relationship with the pupils:

You work well, but it is terrible with the three-year-olds at the beginning of the first term, some of the children were even afraid of me, one of them had the typical reaction of a tummyache as soon as she saw me, or else she was very hungry or very tired, it was all the result of her fear, until one day she came to me and said "teacher, I'm not afraid of you any more», it was great, now she's like everybody else in the group, but to start with it was terrible, she had a very bad time, they are used to their own teacher and there you arrive, a stranger saying strange things, like asking them in English what their names are, and they don't know what you're talking about, it's difficult. But eventually they get used to you, and then everything's all right and they are now working very well (STLSRSGR).

We also check that the children's own pace of activity, play and rest is maintained, in particular regarding the alternation between more formal work, for example activity sheets, and other more informal activities such as story telling, etc, as the same teacher says:

You try to do a little of everything, combining activities, for example, if we do a running game or a dancing song, then we sit down quietly to listen to a story or we fill in an activity sheet, we have to mix lively, physical activities with others which are more relaxed and quiet, so they can rest instead of tiring them out in the first ten minutes. You have to change the rhythm of the lesson (STLSRSGR).

In this way, children can do activities and have experiences which are totally connected to their needs, interests and motivations and so facilitate learning and development.

\subsection{Socialization as a source of relationships and play as a basic principle}

The goal of a methodology of socialisation is to promote personal relationships and contact among all children in the class. This can be achieved by means of alternating between individual and group activities, establishing, according to the different tasks, small and large groups which enable cooperation and socialisation.

Finally, many of the activities, and language-oriented activities in particular, are gamerelated, that is to say, a methodology based on play because play is a basic component of children's development as a source of stimuli, experimentation, enjoyment and fun. One teacher 
says that «I try to do everything in a playful way, for me the most important thing is that they have a good time, so that learning may be an enjoyable game, different each day, by means of which they learn new things every day» (STLSRSGT)

Professor Winnicott (1986: 80) states that «It is only through play that both adults and children can be creative and use their personality as a whole, individuals describe their own personality when they show their creativity. In addition, communication is only possible by means of play.»

Both aspects, language and play, go hand in hand throughout all the stages of a child's development.

The reason why it seems important to mention play in this approach to language learning is explained by Mur (1998: 8): «Children have an enormous capacity to invent and play. By means of their play activities children can really see language. At this stage, games have a central role.»

The way in which children achieve maturity is directly connected to the way in which they associate their inner and outer worlds. Play is the most important aspect when they learn any subject, something which all language teachers must take into account. According to Piaget (in Davenport, 1992: 95) and many other psychologists, children develop play as they grow up. We can observe four kinds of play activities in the classroom:

* Individual play. Children's motor functions allow them to make choices as to which objects they take and which they leave. Particularly during their free time, in between activities, they carry out manipulative tasks and experiment on their own with objects found in the classroom.

* Parallel play. There are also parallel play activities, particularly during break times or longer rest periods. Here we can find them playing with toy cars in the sand, building roads or bridges for their cars. But they do not play together with other children. Each one has his/her own cars and roads. We can even observe conflict if a child tries to interfere with another one's game, getting into the other's road or picking up the other's car.

* Associative play. It appears spontaneously in 5-6 year-old children, and in 3-4 yearolds with the encouragement of teachers.

* Cooperative play. Teachers encourage three or four children to engage in cooperative work.

We can even observe short role-plays and imaginative games. Games are not just mere fun activities which provide real opportunities for the use and assimilation of language while the mind is focused on the game itself, but they also provide very useful opportunities for indirect learning. For this reason Halliwell (1993: 6) thinks that «... games must not be dismissed as a waste of time. Neither must they be considered as a «time filler» at the end of the lesson, nor as a reward for real work, they really are work. They are central elements in the process of language acquisition. Which is just as well because the child has a strong need for games and fun.»

In the same way, Osterrieth (1978: 130) states: «In 3-4 year-olds, the gradual development of language, and play, are the key elements for socialization, even if the child plays only in very small groups of two or three children with very limited communication.» 
One of the teachers stresses this point and refers to the importance of play

... I find it very interesting to note that for example, in Pre-primary School, one of the most important activities at this level is play, however when I talk to colleagues we see that yes, they do play in English but games are sometimes a little too complex because of the instructions, perhaps because it requires cooperation, small group work, and children of this age-group find it quite difficult (QTRSGTO).

Other teachers talk about the complexity of these games:

...in theory this is the basic methodology in Pre-primary School, however, in my and other teachers' experience, these techniques are very complicated; games have to be extremely simple, so I only use very easy games because children find it very difficult to play as they find it hard to follow the rules; it happens for example when you want to play a game with them in the playground, they just want to run, push each other around, play football, whatever, then if you want to organise something with stricter rules it is very difficult, but I'm a very practical person and perhaps I'm not doing it the right way, I always try to find very simple things that they can enjoy and get something positive out of them (QTRSGR).

\subsection{The role of the teachers}

It is very interesting to know the description that specialist teachers make of their own methodology in order to establish whether they are coherent with their own teaching practice. It is fundamental to know the personal interpretation and application of a given method by a teacher, as we have to bear in mind that the method used is not the only variable which determines the success of the teaching-learning process, as Kennedy reminds us (1973: 68):

The repeatedly ambiguous results of these and other attempts to demonstrate experimentally the superiority of one or another foreign language teaching method suggest, it would seem, not only that it is extremely difficult to compare methods experimentally, but also, more important, that methodology may not be the critical variable in successful foreign language teaching.

In respect to these ideas specialist teachers indicate:

I think I use a communicative methodology, of course, I try to get them to reproduce language, to talk, to overcome their fear to speak, it is done in a very playful way because we play a lot and we do everything through games, songs and things like that (STLSRSGR).

As to the methodology I use, let's see, I base everything on auditory and visual intelligence. That is, everything through kinaesthetic and Total Physical Response activities. I use gestures to emphasize everything I say and I always ask children to make the gesture first and then we do everything else. Perhaps they begin by 
making the gesture, for example they put a hand to their tummy and rub it a little and then I say "I'm hungry" and after they automatically follow it up. But it is always like this and I also use songs (STLSRSGTO)

As we can see, they do not identify a specific methodological technique, but rather enumerate the sequence activities they follow, which define the teaching style of each teachers.

Another aspect which has also been referred to is the role of the teachers in these work sequences.

Here is the transcription of some of them:

The teacher can play many roles, apart from being the instructor, educator and all that, in my opinion the most important role is to be a stimulator because the first thing a teacher has to do is to create an atmosphere for learning, show a video, play a song, whatever, so the presence of the teachers is not necessary, but what the teacher has to do is to create an atmosphere for learning and then when that atmosphere is created the teacher becomes a stimulator; very often what may happen is that the silence in class is broken by a lot of noise but that noise can be controlled and I think that it is very positive. It is very positive to give children guidelines so that they can learn to learn by learning, they begin to learn and they are a little in control of their own learning, aren't they? Of course there's a bit of noise but I think it's controllable and as I say, I think the most important thing is to be a stimulator (STLSRSGTO).

The teacher becomes the motivator of learning. In the following example the teacher chooses to take on a different role, that of leader and coordinator. In both cases the practical difference is hardly noticeable, as what both of them want is to keep the children active and have them produce words in English. One teacher says:

I don't see myself in a controlling role, I'm not the one who organizes everything, in fact I think that we are really like guides, you provide the guidelines and teach them a number of basic steps to follow, but I think our role is to show them the way. Of course, the little ones perhaps need to have more precise guidelines because they need to get used to rules, rules of behaviour, not like in Victorian times, I mean, but there are some rules of behaviour towards the teacher and the classmates, respect, cleanliness, hygiene, but I think ours is a guiding role, showing stories, of course, giving them confidence, and if you see the child is lost or not doing the task correctly, you have to say, it's not like that, you have to do it like this, but not in the old-fashioned way» (STLSRSGT).

We can summarise all these activities using the words of Brown (1987: 195): «The teacher's task is to value the learners, prize their attempts to communicate, and then to provide optimal feedback for the system to evolve in successive stages until learners are communicating meaningfully and unambiguously in the second language.»

It is also interesting to note the point of view that the schools' head teachers have about the methodology used by the specialist teachers. One of the head teachers shows her concern, indicating the evident lack of an appropriate methodology for the teaching of foreign languages, 
since grammar content is given more importance than the oral aspects, and establishing a comparison with the systems used in other countries where the final level of knowledge of a foreign language is higher than in our country in spite of their devoting fewer years to its study: "There is a lack of oral content and discourse ability, you may have a lot of knowledge about syntax, spelling, but if you don't possess oral skills, if you can't converse or if you are unsure as to pronunciation then it's no use» (IHRSGT).

The above mentioned head teacher finds it absolutely essential that language should be used from a communicative point of view, and not just seen, as very frequently happens, as mere written reproduction. This teacher is in favour of a modern approach centred on the pupils' interests, using for example, present day music to motivate and awaken their interest: «Well, the fact is that maybe after fourteen, thirteen or ten years studying English or French you are never capable of speaking it» (IHRSGTO).

This teacher proposes a solution which is the use of a more holistic approach, where specialist teachers are trained to understand the complexities of the specific characteristics of Pre-primary Education pupils in order to ensure more efficient language teaching and learning at this level:

I believe that, generally speaking, the great problem with the methodology of English is that the methodological approach is not globalised with regard to the other areas of Pre-primary Education and it is seen as English, starting from Spanish; that is to say, I teach English but in a one-hour long lesson I use Spanish for twenty minutes, there's no emphasis on oral production, that is, total immersion in the language, as is the case with Galician or Spanish (...) (IHRSGR).

\section{Discussion}

As we have seen in the data provided by the various documents analysed, the problem of the methodology used to teach English in Pre-primary School ends up by affecting all levels of teaching. As Widdowson (1979: 117) states: «The problem is that students, and especially students in developing countries, who have received several years of formal English teaching, frequently remain deficient in the ability to actually use the language, and to understand its use, in normal communication, whether in the spoken or the written mode», and Spain is a clear example of the fact that, in spite of the number of years dedicated to the study of a foreign language, the results are to say the least mediocre. This same author suggests a number of solutions along the lines of the solutions suggested by the participants in this study:

What I should like to suggest is that we should consider ways of adapting the present approach to the teaching of English so as to incorporate the systematic teaching of communicative value. I would propose that in the process of limitation, grading, and presentation, we should think not only in terms of linguistic structures and situational settings, but also in terms of communicative acts. (...) It would, of course, be a mistake to devote attention exclusively to communicative acts in the preparation and presentation of language-teaching materials. In the teaching of language, one has continually to make compromises and to adjust one's approach 
to the requirements of students and the exigencies of the teaching situation. It would be wrong to be dogmatic. All I wish to suggest in this article is that some adjustment to the approach generally recommended at present is needed in that it appears not to be adequate in its present form: it does not seem to provide for the teaching of the knowledge of how English is used to communicate (Widdowson, 1979: 119-120).

Language is essentially communication and for that reason when we envisage its teaching we must always bear that in mind. The main goal of our methodology must be to train our students so that they can express themselves easily in that language, thus allowing them to communicate with people from other backgrounds and cultures (de Bot, Lowie \& Vespoor, 2006).

We have also verified that the methodological situation of English teaching in Pre-primary School poses very specific problems and requires special development, taking into account the possibilities and needs of children of this age; as Professor Phillips (2001) explains, language learning can be introduced at an early age if the conditions are adequate. With reference to pre-school the methodology I would advocate is: teaching areas such as music, art and movement through English (as in the Lollipop project in Austria); the use of simple songs (often specially written). The songs native children learn often contain archaic language and the meaning is obscure even to native speakers; the use of Big Books, both authentic and specially written, which are profusely and attractively illustrated. The first consideration in choosing these books should not be language as conceived in the typical ELT text book (i.e. a grammar-based syllabus), but should be how the book integrates in the topic the language teacher and the class teacher are working on; no reading and writing as such, though if the children know their letters then the teacher may like to focus on words with first letters that the children easily recognize; short extracts of video related to the themes in question, using characters that the children will recognise or relate to; simple computer games in $3^{\circ}$ of infantile; very simple games, similar to the ones the children play in their own language.

All the factors analysed show external influences; teachers must exploit them to their advantage, but above all, must find their own way, focusing on a series of aspects summarised by Halliwell (1993: 9) when he says that teachers must give priority to:

1. Focusing methodology on the natural capacities and instincts that children bring into the classroom.

2. Working towards attitudinal as well as conceptual objectives.

3. Ensuring that activities which really use language are done as part of the learning process, and not only as the intentional result of it.

In these schools games are very useful and important, not only because they are fun, but partly because the play element creates a need to communicate, and partly because games can give rise to unpredictable situations.

Among the most common games we find guessing games, where children have to guess a word or a sentence; these are very good examples of indirect learning. The children do not try to learn the sentence because they are concentrating on guessing it. But when the activity is finished, they will have acquired words and expressions which were only vaguely familiar 
before the game. They will be fixed in their minds. In many cases we can also observe that pronunciation has improved. In fact, it is a very good way to learn sentences and structures, but it is indirect as the mind is engaged in the task rather than focused on the language. It follows the same process as with the mother tongue, which is acquired through immersion and usage, not in a conscious way.

Both direct, conscious learning and indirect learning or acquisition, help children make the new language theirs. Experience indicates that both systems are used in part. The use of one of these systems to a larger extent than the other depends on a combination of intellectual development, character and circumstances (Lantolf and Thorne, 2006). In practice, all of them play an important role. Direct conscious learning seems to encourage accurate elaboration of the language, whereas unconscious indirect learning stimulates the spontaneous, and therefore more fluent, use of the language. The ideal situation would be the development of accuracy and fluency. Thus, opportunities for using both systems must be offered in the classroom. Teachers must be very clear as to what kind of learning is most appropriate at any given time, so that children may know the aim of the activities which they are carrying out.

Summing up on the principles found to contribute to successful program development in the teaching of English as a forein language in Pre-primary levels we can point out: parental involvement, positive attitudes toward the target language and culture, creating a natural setting in which language can be used in a meaningful way, paying attention to the social, affective and cognitive domains of learning, providing broad exposure to the target language, promoting substantial student initiation of communication, and incorporating role-playing and dramatization, games, theme-based lessons and problem-solving, and discovery. Therefore the learning should be an enjoyable; confidence building and successful experience for the learner.

\section{BibLIOGRAPHICAL REFERENCES}

Ashworth, M. and Wakefield, H.P. (1994). Teaching the World's Children ESL for Ages Three to Seven. Markham, Ontario: The Pippin Teacher's Library.

Brewer, J. and Hunter, A. (1989). Multimethod Research. A Synthesis of styles. Newbury Park: Sage Publications.

Brown, H. D. (1987). Principles of Language Learning and Teaching. New Yersey: Prentice-Hall.

Brunfit, C.J., Moon, J. and Tongue, R. (1991). Teaching English to Children. From Practice to Principle. London: Nelson.

Chamot, A. U. et al. (1999). The Learning Strategies Handbook. New York State: Longman.

Chamot, A.U. (2004). «Issues in language learning strategy research and teaching», Electronic Journal of Foreign Language Teaching 1:14-26, available from: http://e-flt.nus.edu.sg/ v1n12004/chamot.htm. accessed 15 june, 2009.

Cohen, A. D. (1998). Strategies in Learning and Using a Second Language. London: Longman.

Cohen, A.D. and Macaro, E. (Eds) (2007). Language Learner strategies: thirty years of research and practice. Oxford: Oxford University Press.

Colé, M.P. (1994). Evaluación en el segundo ciclo de Educación Infantil. Madrid: Escuela Española.

Davenport, G.D. (1992). Essential Psychology. London: Collins Educational.

Del Rincón, D., Arnal, J., Latorre, A., and Sans, A. (1995). Técnicas de investigación en ciencias sociales. Madrid: Dykinson. 
De Bot K., Lowie W. \& Vespoor M. (2006). Second Language Acquisition: An avanced resource book. New York: Routledge.

Dunn, O. (1983). Developing English with Young Children. London: Macmillan Publishers.

Dunn, O. (1985). Beginning English with Young Children. London: Macmillan Publishers.

Ellis, R. (1994). The study of Second Language Acquisition. Oxford, Oxford University Press.

Gálvez Díaz, D.J. (dir.) (2001). Enseñanza del Inglés en el Segundo Ciclo de Educación Infantil. Badajoz: Junta de Extremadura.

Goetz, J.P and LeCompte, M.D. (1988). Etnografía y diseño cualitativo en investigación educativa. Madrid: Morata.

Halliwell, S. (1993). La enseñanza del Inglés en Educación Primaria. Essex: Longman.

Kennedy, M. (1991). An Agenda for Research on Teacher Learning. Michigan State University: National Center for Research on Teacher Learning.

Lantolf JP. And Thorne SL. (2006). «Sociocultural theory and second language learning», in Van Patten, B. and Williams J. (eds.), Theories in second language adquisition. New York: Routledge. Mahwah, NJ: Erlbaum, 201-224.

López Rodríguez, J.C. (2001). Inglés en la escuela rural. Cuadernos de Pedagogía, 300: 30-33.

Marshall, C. and Rossman, G.B. (1989). Designing qualitative research. Newbury Park: Sage Publication.

Mur, O. (1998). Como introducir el Inglés en Educación Infantil. Madrid: Escuela Española.

Navarro, P. and Díaz, C. (1994). «Análisis de Contenido», in Delgado, J.M. and Gutiérrez, J., (eds.), Métodos y técnicas cualitativas en Ciencias Sociales. Madrid: Síntesis.

O’Malley, M. and Chamot, A. U. (1990). Learning Strategies in Second Language Acquisition. Cambridge: Cambridge University Press.

Osterrieth, P.A. (1978). Psicología infantil: introducción a la psicología infantil: de la edad bebé a la madurez infantil. Madrid: Ediciones Morata.

Oxford, R. (1990). Language Learning Strategies; What Every Teacher Should Know. Boston, MA: Heinle and Heinle.

Phillips, S. (2001). Young Learners. Oxford: Oxford University Press.

Rodríguez Gómez, C., Gil Flores, J. and García Jiménez, E. (1999). Metodología de la investigación cualitativa. Málaga: Aljibe.

Rodríguez Sánchez, M.T. and McArthur, F. (2001). Lenguas extranjeras en la etapa de Educación Infantil. Badajoz: Junta de Extremadura.

Stern, H.H. and Weinrib, A. (1977). «Foreign languages for younger children: trends and assessment», in Language Teaching and Linguistic Abstracts, 1, 10: 152-172.

Widdowson, H. (1979). Explorations in Applied Linguistics. Oxford: Oxford University Press.

Winnicott, D.W. (1986). Realidad y juego. Barcelona: Gedisa.

\section{Acronyms}

RSG: Rural School Groups - Colegios Rurales Agrupados

L1: Mother tongue

L2: Second Language

IHRSGR: Interview Head teacher O Rosal Rural School Group - Entrevista Director Colegio Rural Agrupado O Rosal

IHRSGT: Interview Head teacher Tui Rural School Group - Entrevista Director Colegio Rural Agrupado Tui -

IHRSGTO: Interview Head teacher Tomiño Rural School Group - Entrevista Director Colegio Rural Agrupado Tomiño 
STLSRSGR: Specialist Teacher Life Story O Rosal Rural School Group - Historia de Vida Profesor Especialista Colegio Rural Agrupado O Rosal

STLSRSGT: Specialist Teacher Life Story Tui Rural School Group - Historia de Vida Profesor Especialista Colegio Rural Agrupado Tui

STLSRSGTO: Specialist Teacher Life Story Tomiño Rural School Group - Historia de Vida Profesor Especialista Colegio Rural Agrupado Tomiño

QTRSGTO: Questionnaire Tutor Tomiño Rural School Group - Cuestionario Profesor Tutor Colegio Rural Agrupado Tomiño

QTRSGR: Questionnaire Tutor O Rosal Rural School Group - Cuestionario Profesor Tutor Colegio Rural Agrupado O Rosal 
